\title{
口蓋裂例の中耳疾患と耳管の病態
}

\author{
田坂康之
}

\section{Middle Ear Disease and Eustachian Tube Function in Patients with Cleft Palate}

\author{
Yasuyuki Tasaka \\ (Kyoto University)
}

\begin{abstract}
It has been well known that patients with cleft palate have a high incidence of middle ear disease. Etiology of the ear disease however is still obscure. Dysfunction of the eustachian tube which accompanied by cleft has been considered to be one of the etiological factors of frequent ear disease in cleft palate patient.

To clarify the association between middle ear disease and eustachian tube, otological, endoscopical and functional studies of the eustachian tube were carried out in $263 \mathrm{cleft}$ palate patients (526 ears).

The results were as follows:

1. Otitis media with effusion was most common (33\%) in cleft palate cases, but neither the type of cleft, side of cleft nor velopharyngeal insufficiency had any correlation with the incidence of middle ear disease, suggesting that cleft palate patients had common pathological conditions to both eustachian tubes.

2. A variety of abnormal movements were seen in pharyngeal orifices of the eustachian tube. More than half of them showed no dilation of the tube, indicating either hypofunction of the tensor muscle or abnormal pathway of the levator muscle.

3. The mean opening pressure of the tube was lower in OME patients with cleft palate than those without cleft, indicating that decreased closing force was a pathogenic factor of OME in the cleft palate cases.

4. Almost all ears of OME, and more than half of the normal ears in cleft palate patients could not equilibrate applied negative middle ear pressure during swallowing. Thus disturbance of dynamic ventilatory function of the tube seemed to be prevalent in the cleft palate cases, causing a high incidence of middle ear disease.

5. Ciliary function of the tube in cleft palate patients was generally good with less etiologic significance.
\end{abstract}

Key words: middle ear disease, cleft palate, eustachian tube 


\author{
目次 \\ I はじめに \\ II 口蓋裂と耳疾患 \\ 1 目的 \\ 2 対象亡方法 \\ 3 結 果 \\ （1）耳疾患の種類と頻度 \\ (2) 裂型と中耳疾患 \\ (3) 裂側と中耳疾患 \\ （4）鼻咽腔閉銷不全と中耳疾患
}

\section{4 考 按}

III 耳管咽頭口の内視鏡的所見

1 目的

2 対象亡方法

3 結 果

（1）口蓋裂例の耳管咽頭口の運動

(2) 耳管咽頭口の異常と中耳疾患

4 考 按

IV 滲出性中耳炎を持つ口蓋裂例の耳管機能

1 目 的

2 対 象

3 耳管機能検査法

(1) 静的耳管機能

(2) 動的耳管機能

(3) 耳管の排泄能

（4）圧負荷音響耳管検査

(5) 鼻すすり検査

4 結 果

(1) 耳管の静的検査

(1) 耳管通気圧

\section{I はじめに}

1878年，Alt ${ }^{1)}$ が口蓋裂の耳疾患について記 載して以来，口蓋裂例に滲出性中耳炎をはじめ 中耳疾患が多いととはよく知られている。しか し耳疾患多発の原因については多くの研究に屯 かかわらず不明な点が多い.

従来その原因の一つに，鼻咽腔閉鎖不全によ る耳管咽頭口の污染説 ${ }^{2)}$ がある. これは口腔と 鼻腔との不完全な遮断が耳管咽頭口の污染ひい ては耳管炎を来し，滲出性中耳炎を惹起すると するあのである。乙れとは別に耳管に関係する
(2) 耳管の陽圧保持能

(3) 圧負荷音響耳管検査

(4) 鼻すすり検査

(2) 耳管の動的検査

(3) 耳管の排泄能検査

5 考 按

(1) 耳管の静的機能について

(2) 耳管の動的換気能について

(3) 耳管の排泄能について

6 小括

V 口蓋裂例片側滲出性中耳炎例の非罹患耳の 耳管機能

1 目 的

2 対 象

3 結 果

4 考 按

VI 口蓋裂滲出性中耳炎難治例の耳管機能

1 目 的

2 対 象

3 結 果

（1）難治群の耳管機能

（2）治癒群の耳管機能

4 考 按

（1）静的耳管機能の比較

（2）動的耳管機能の比較

(3) 排泄能の比較

5 小括

VII 総 括

VIIIまとめ

筋肉（口蓋帆挙筋，口蓋帆張筋）の走行異常 ${ }^{3)}$ や附着異常 ${ }^{4)}$ が耳管の開大を妨げるとする考え があり，筋切断による実験的な裂形成で滲出性 中耳炎を発生させたという報告がある ${ }^{516)}$. 一 万，口蓋裂に伴う耳管全体の解剖学的な異常 ${ }^{7)}$ が耳管の機能不全，ひいては中耳疾患を若起す る可能性も否定できない.

本研究では口蓋裂例の中耳疾患と耳管の病態 との関係をより明らかにする目的で，多数の口 蓋裂例を対象に中耳疾患の頻度と裂のタイプや 裂側との関係，さらに鼻咽腔閉鎖不全と中耳疾 
患との関係を調べた。また内視鏡による耳管咽 頭口の異常運動の観察結果と中耳疾患との関係 を調べた，更に口蓋裂例に多発する滲出性中耳 炎に的を絞り，これらの耳管機能を各種の耳管 検查法で総合的に調へ，最終的には，片側性中 耳炎や滲出性中耳炎の難治例など特殊例の耳管 機能を口蓋裂一般のそれと比較することで，口 蓋裂例に共通する耳管の病態の特徵を明らかに しようとした。

\section{II 口蓋裂と耳疾患}

1 目的

口蓋裂例での中耳疾患の発症頻度, 年齢との 関係を調べた。また従来議論のある口蓋裂の裂 型，裂側および鼻咽腔閉鎖不全の因子と中耳疾 患との関係を再調査して, 裂の程度や耳管咽頭 口污染の因子と中耳疾患の発症との関係を調べ た.

\section{2 対象と方法}

口蓋裂263例（526耳）を観察の対象とした。

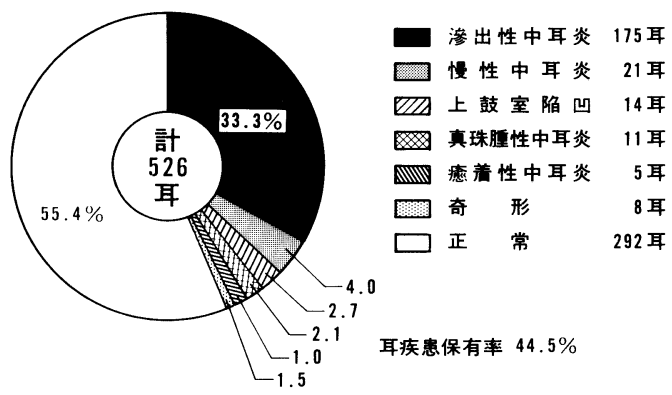

図1口蓋裂例の耳疾患

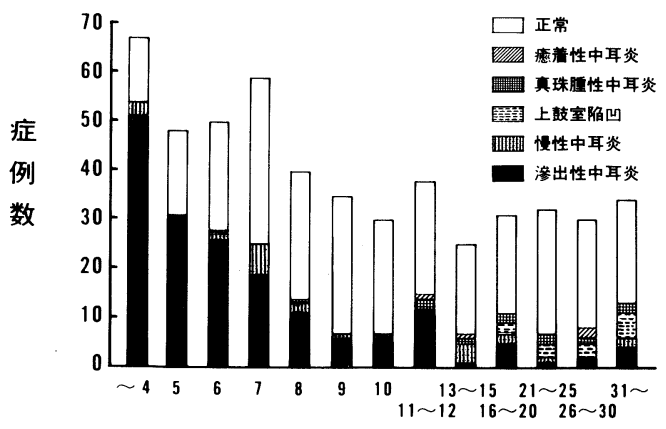

年

図 2 口蓋裂例の年歯別耳疾患
年齢は 0 歳から 71 歳 (平均12歳)，うち既手術 247例（494耳)，未手術16例（32耳）であった. 鼻咽腔閉鎖不全のみの因子が中耳疾患に及ぼ す影響を調べるために，口蓋裂のない先天性鼻 咽腔闒鎖不全症 16 例（32耳）屯観察の対象之 した.

拡大耳鏡や顕微鏡による鼓膜の詳細な視診の 後, 聴力検査, インピーダンスオージオメトリ 一，リフレクトメトリーで中耳疾患の鑑別診断 を行った。 また滲出性中耳炎が疑われる場合は 鼓膜穿刺，切開などで診断を確定した。

3 結 果

(1) 耳疾患の種類と頻度

滲出性中耳炎175耳 (33\%) を最多とし慢性中 耳炎, 上鼓室陥凹, 耳真珠腫, 癒着性中耳炎が みられ，中耳・内耳の奇形を含めると口蓋裂例 の耳疾患の罹患率は44.5\%に達した。乙れら耳 疾患の中で滲出性中耳炎が占める比率は $74.8 \%$ と高率であった（図 1 ）。

年齢別にみると，滲出性中耳炎は年齢と共に 減少するが，逆に真珠腫，癒着性中耳炎，上鼓 室陥凹など滲出性中耳炎の後遺症と思われる慢 性疾患は 10 歳を境に増加することがわかった (図 2 ).

（2）裂型と中耳疾患

裂型間では中耳疾患の罹患率に有意差を認め なかったが，粘膜下口蓋裂のみ有意に中耳疾患 が少なかった（図 3 ）。また粘膜下口蓋裂では既

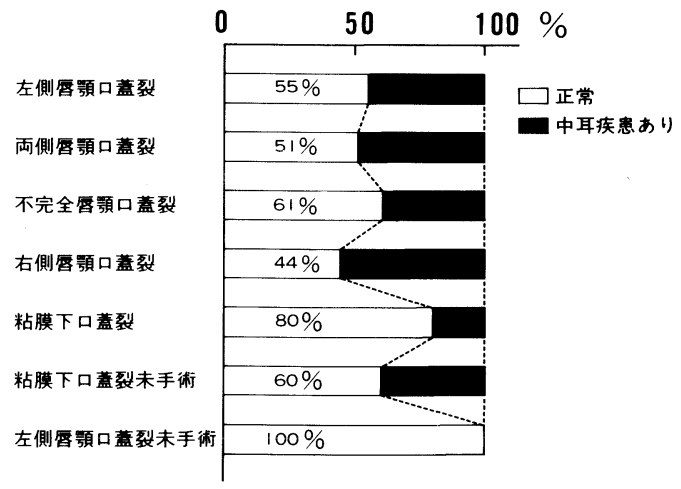

図 3 裂型と中耳疾患との関係 
手術群の方が未手術群より耳疾患が有意に少な かった。

（3）裂側と中耳疾患

中耳疾患の状態を，(1)両耳と屯正常，(2)両耳 と屯異常，(3)右耳のみ正常，(4)左耳のみ正常の 4 群に分け，口蓋裂のタイプと耳疾患との関係 を調べた所，各裂型とも両耳正常加両耳異常か が $81 \%$ を占め，片側性の耳疾患は少ないとと がわかった。 また右側裂，左側裂では裂側と 眻患側との間に全く関係が認められなかった (図 4 ).

（4）鼻咽腔閉銷不全と中耳疾患

未手術の粘膜下口蓋裂 32 耳と，同じく未手術 のいわゆる鼻咽腔閉鎖不全症例 $36 耳$ 耳中耳疾患 の罹患率を比較した所，前者の $41 \%$ に対し，後 者では $5.6 \%$ (奇形を除く) と有意に罹患率は少

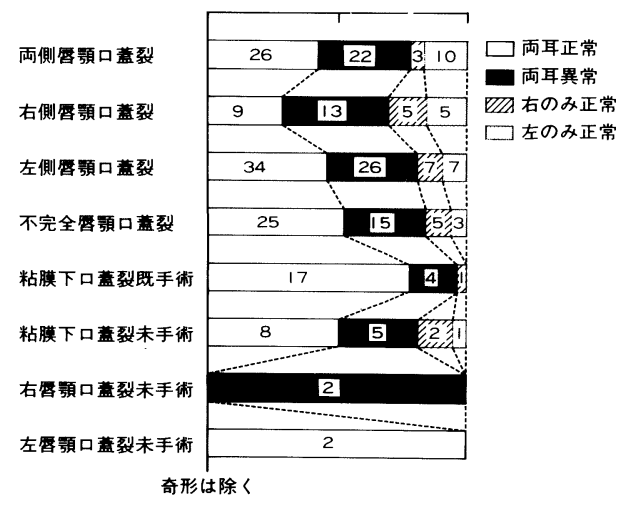

図 4 裂側と中耳疾患との関係

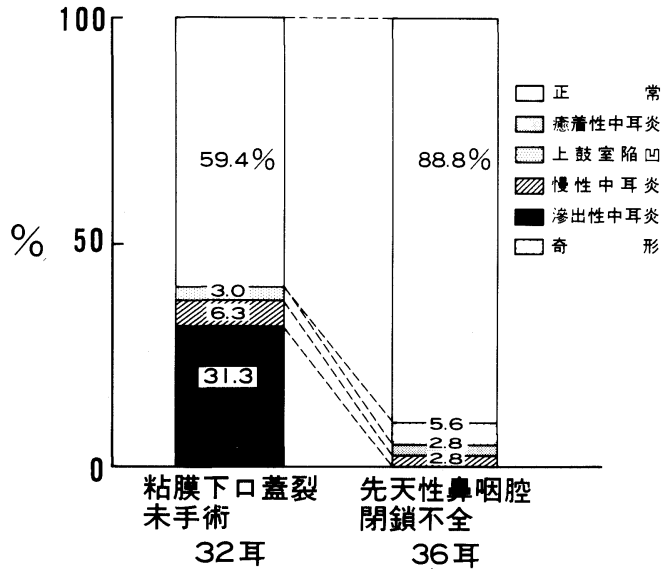

図 5 鼻咽腔閉銷不全と中耳疾患との関係
なく, 滲出性中耳炎に限れば後者には罹患例が 全くみられなかった（図 5). 両群は等しく鼻咽 腔閉鎖不全の因子を有しており，相違点は口蓋 裂（筋層）の有無だけであるので，少なくとも 滲出性中耳炎と鼻咽腔閉鎖不全との関係は極め て少ないととがわかった。

\section{4 考 按}

今回観察の対象とした口蓋裂例の一部は構音 障害や鼻疾患などの愁訴で受診した例であり， 平均的な口蓋裂例の中耳病態を必ずし屯示して いるとはいえないが，耳疾患の罹患率は $44.5 \%$ に達し，口蓋裂例に耳疾患，特に滲出性中耳炎 が多発するととが再確認された. また既報8) 10) のように，低年齢ほど滲出性中耳炎の罹患率が 高いこと，真珠腫など重篤な中耳疾患をもつ例 が年長者に多くなることむ確認された。

このような口蓋裂例における中耳疾患多発の

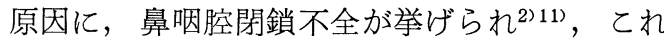

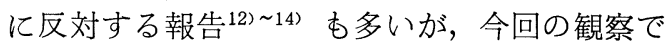
少なくと屯滲出性中耳炎の病因として鼻咽腔閉 鎖不全の可能性は少ないととが示された。また 裂側や裂型と耳疾患との間に相関を認めなかっ たとと，片側性の耳疾患が少なかったととは， 共に従来の報告 ${ }^{15) ~ 19) ~}$ と一致し，口蓋裂では両 側の耳管に障害を来す共通の基盤があるととが 推察された。

\section{III 耳管咽頭口の内視鏡的所見}

\section{1 目的}

口蓋裂の耳管の形態的観察は，剖検例の検 討20) 23) や耳管のX線造影法 ${ }^{24)} ， \mathrm{CT}$ スキャン などが行なわれており，三苫ら ${ }^{25)}$ は内視鏡的観 察により，曣下や発声時に耳管に矛盾運動があ り，乙れが口蓋帆挙筋や帆張筋の走行，付着の 異常によることを報告している.

本研究では同じく経鼻的なフレキシブルファ イバースコープにより，耳管咽頭口の形態や動 態をより詳細に観察し，乙れが中耳疾患とどの 様に関係しているのかを調べた。

\section{2 対象之方法}

口蓋裂 201 例（402耳）を対象とし，直径 3.7 
$\mathrm{mm}$ または $4.5 \mathrm{~mm}$ の軟性ファイバースコープ (OLYMPUS ENF-P,L) を一側の鼻孔から上咽 頭に入れ，耳管咽頭口の動きを嚥下，開口，発 声時に観察し，同時にVTR に録画した。

3 結 果

（1） 口蓋裂例の耳管咽頭口の運動

與下，開口など耳管咽頭口が開大すべき際に, 耳管咽頭口が開大するもの $(58 \%)$ ，不変のもの (34\%)，逆に閉塞するあの（8\%)の 3 種がみ られた（図 6 )。 うち耳管咽頭口の非開大例で は，(1)咽頭口が正常のろうと状を呈さず，開大

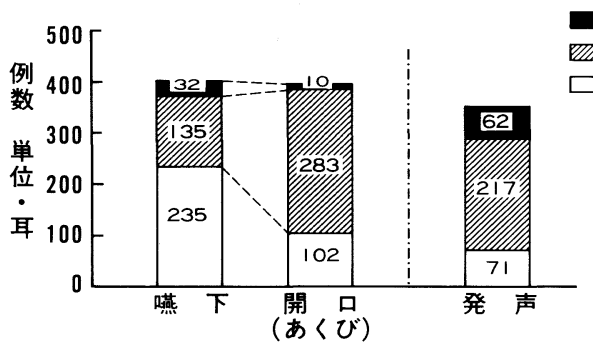

図 6 耳管咽頭口の運動

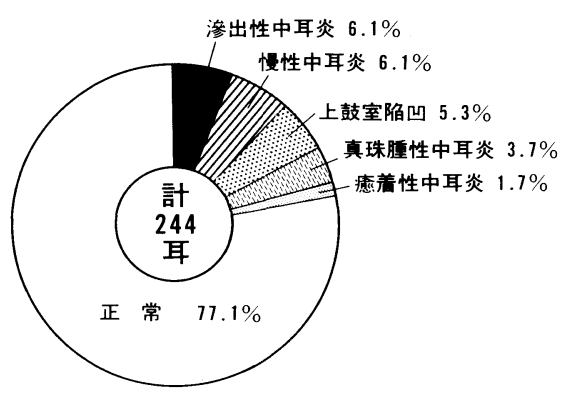

図 7 耳管咽頭口開大群の中耳疾患

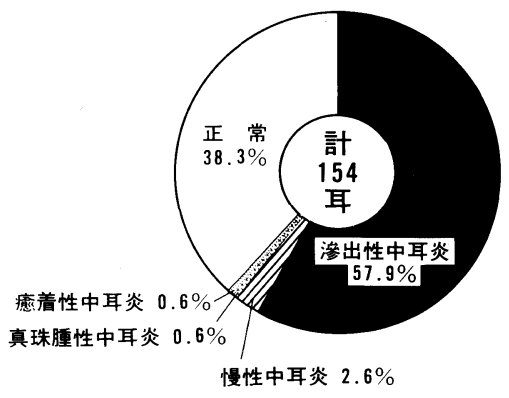

図 8 耳管咽頭口非開大群の中耳疾患
の判定ができないもの (23\%)，(2)咽頭口はろう 之状を呈すが，耳管の開大には至らないもの (77\%)，に大別できた。逆に耳管咽頭口が閉鎖 する例は，(1)耳管底部を形成する挙筋隆起が挙 上し咽頭口を閉塞するもの (75\%)，(2)前唇や後 唇が変位して咽頭口を被うあの (25\%)，に分け られた。 また発声時は通常耳管咽頭口は開大し ないあのであるが，逆に開大がみられたあの 20 \%（71耳）であった．全体として口蓋裂例にお ける耳管咽頭口の開大障害は $40 \%$ に存在するこ とがわかった。

(2) 耳管咽頭口の異常と中耳疾患

耳管咽頭口に開大がみられる群とそうでない 群での中耳疾患の割合は，図 7 の様に耳管咽頭 口開大群では $23 \%$ と少なく, 疾患の種類屯滲出 性中耳炎，慢性中耳炎，上鼓室陥凹，耳真珠腫 が均等に見られた。一方非開大群では中耳疾患 の罹患率は $62 \%$ 之高く，うち滲出性中耳炎が58 \%を占めた（図 8).

\section{4 考 按}

耳管咽頭口の異常運動，すなわち䁵下で咽頭 ロが開大しない例や閉塞する例，発声で咽頭口 が開大する機序として口蓋帆挙筋の走行異常や 付着部の異常 ${ }^{26)}$ ，あるいは口蓋帆張筋の先天的 な低形成, 手術による筋自体や支配神経の損 傷27)などが考えられる，先に我々 ${ }^{28)}$ は，口蓋 裂の耳管の核磁気共鳴画像から，耳管軟骨の咽 頭側にカップ状の変形と, 同部の耳管粘膜の著 明な浮腫，口蓋帆挙筋の位置と走行の異常とを 報告したが，これらの口蓋裂例にみられる耳管 筋の形態異常が耳管咽頭口の異常運動の原因の 一つと考えられた。また，耳管咽頭口が口蓋帆 挙筋の収縮に際し容易に変形し, 咽頭口の異常 運動を来すのは，耳管の枠組みが軟弱なためと 考えられた。

\section{IV 淩出性中耳炎を持つ口蓋裂例の耳管機能}

\section{1 目的}

口蓋裂例で罹患する率が最も高い滲出性中耳 炎に焦点を絞り，中耳の病態と耳管の機能との 関係を調べた。 
2 対 象

滲出性中耳炎をむつ口蓋裂例 107 耳を観察の 対象とした。年齢は 4 歳から50歳 (平均 8 歳), 既手術例が98耳（91.6\%）と大半を占め，未手 術例は粘膜下口蓋裂例の 9 耳のみであった。治 療としては鼓室チューブの留置を行い，不能例 にのみ鼓膜切開を行なった。 また滲出性中耳炎 を持つ非口蓋裂 $261 耳$ 耳 (老人を除く)をコントロ ールとした。

3 耳管機能検査法

(1) 静的耳管機能

滲出性中耳炎をあつ口蓋裂例 107 耳 の中耳 陽圧を負荷し，耳管が受動的に開く圧が定常化 した時の圧を耳管の通気圧とした (Gould P-23 ID 圧トランスジューサーを使用)。 既報 ${ }^{29)}$ に 従い正常耳管の通気圧は165～545ミリ水柱とし た. 次に数回の䀻下の後, 200 ミリ水柱の陽圧を 負荷し，乙れを約 3 秒保持できるか否かを調べ た（陽圧保持テスト）.

(2) 動的耳管機能

さきの 107 耳に 200 ミリ水柱の陽圧を中耳に負

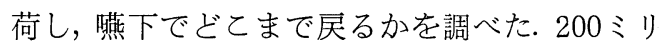
水柱の陽圧が負荷できない例には150，100，50 と負荷圧を下げて検査を行った（陽圧テスト）. 次に-200ミリ水柱の陰圧を中耳に負荷し, 與 下での圧解除能を調べた (陰圧テスト). 判定は 既報29) 亿従い，陽圧テストでは負荷圧を半分以 下まで軽減できる屯のを良好，陰圧テストで は少しであ負荷圧を軽減できるあのを良好と した。

(3) 耳管の排泄能

63耳の中耳に $0.02 \mathrm{cc}$ のインジゴカルミンを 滴下し，乙れが耳管咽頭口から排出されるまで の時間を経鼻的内視鏡で測定した. 判定法は既 報299に従い15分以内を正常值とした。

（4）圧負荷音響耳管検査

43耳を対象とし既報30) の様に鼓室チューブ を介して中耳に圧を負荷し，鼻腔から入れた音 の伝導性が耳管を介して外耳道側でどう変るか を調べた。
（5）鼻すすり検査

口蓋裂例にみられる閉鎖力の弱い耳管では, 鼻すすりが中耳圧に影響をおよぼす可能性があ

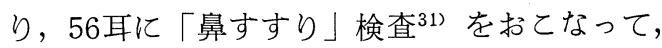
鼻咽腔圧の中耳への波及を調べた。

4 結 果

(1) 耳管の静的検査

(1) 耳管通気圧

口蓋裂例の耳管通気圧の平均は $274 \pm 132$ ミリ

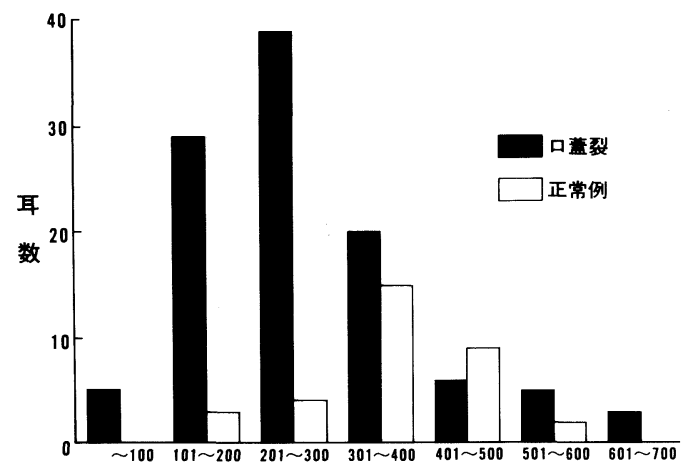

耳管通気圧 $\mathrm{mmH}_{2} \mathrm{O}$

図 9 滲出性中耳炎例の耳管通気圧

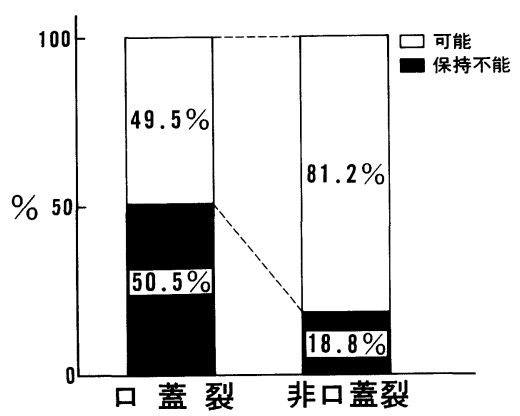

図10 滲出性中耳炎例の耳管の陽圧保持能

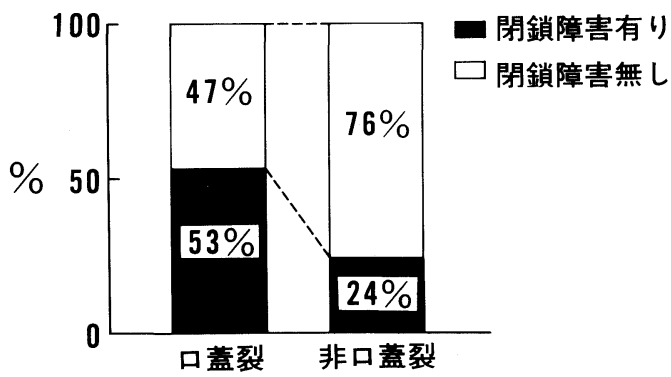

図11 滃出性中耳炎例の耳管の閉鎖障害 
水柱であり，コントロールとした外傷性鼓膜穿 孔耳33耳に較べ有意に低いととがわかった（危 険率 $1 \%$ 以下，Welch-t-test）（図 9)。また非口 蓋裂例261耳では，通気圧低值群が6. $1 \%$ (15耳) なのに対して，口蓋裂例では $25.2 \%$ (27耳）と 有意に低值例が多かった（危険率 $1 \%$ 以下， $\chi^{2}$ test)。 また非口蓋裂例では最大 800 ミリ水柱の 陽圧でも耳管が開かない耳管閉塞例が13\%（34 耳）にみられたが，口蓋裂例では全くみられな かった。

(2) 耳管の陽圧保持能

口蓋裂例では陽圧保持不能例が54耳 (50.5\%) と半数にみられたが，口蓋裂のない滲出性中耳 炎耳では不能例はわずか $18.8 \%$ (49耳) であり， 口蓋裂例の耳管が有意に陽圧保持能力が低いと とがわかった $\left(\chi^{2}\right.$-test) (図10).

(3) 圧負荷音響耳管検査

耳管の閉鎖障害例は53.5\%（23耳） 之過半数 を占め，口蓋裂のない滲出性中耳炎例に較べ て耳管の閉鎖力が有意に弱いととがわかった (図11).

(4) 鼻すすり検査

本検査で中耳に陰圧を生じた例は19.6\%（11 耳）であり，乙れらの耳管通気圧は平均 $97.3 \pm$ 95.5 ミリ水柱と低值を示した.

(2) 耳管の動的検査

陽圧テスト良好例は $50.5 \%$ （54耳）と約半数 であったが，陰圧テスト良好例は6.5\%（7 耳） のみであり，残る $93.5 \%$ (100耳) は陰圧を解除 する機能が障害されていた（図12）.

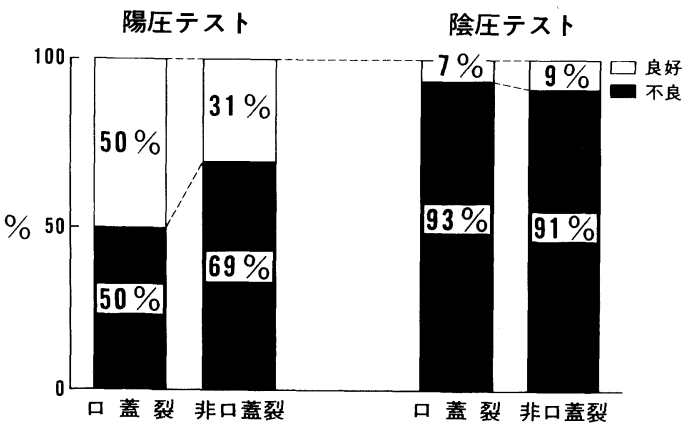

図12 滲出性中耳炎例の耳管の動的換気能
一方口蓋裂のない滲出性中耳炎例では陽圧テ スト良好例は $31 \%$ であり，陰圧テスト良好例は $9 \%$ あった。

(3) 耳管の排泄能検査

71. $4 \%$ （45耳）が正常であった.

5 考 按

(1) 耳管の静的機能について

耳管通気圧の測定結果から，口蓋裂例の滲出 性中耳炎例では，耳管の閉塞例が全くみられ ず，耳管の器質的狭窄が滲出性中耳炎の原因之 は考えにくいことがわかった。一方過半数で中 耳の陽圧保持能が障害されており，滲出性中耳 炎を持つ口蓋裂例では耳管の閉鎖力が弱いこと がわかった．また耳管の閉鎖力の他の検出法で ある圧負荷音響耳管検査であ，過半数に耳管の 閉鎖障害が認められ，滲出性中耳炎をあつ口蓋 裂例の耳管の特徵に閉鎖障害があることが明ら かとなった。

口蓋裂例の解剖学的異常の報告では，耳管軟 骨の変形32) や，耳管の頭蓋に対する相対的な位 置異常による筋のベクトルの変位 ${ }^{20)}$ ，耳管筋の 形成不全や筋周囲の線維化 ${ }^{33)}$ などが指摘され ており，Doyle ${ }^{34) 35)}$ らは口蓋形成術後に有意に 耳管の 通気圧が低下することを報告している が，口蓋裂例の耳管の閉鎖障害はこのような解 剖学的条件に由来するあのと考えられた。

一方 Falk ${ }^{36)}$ は鼻すすり検查で口蓋裂例の過 半数に中耳の高度陰圧化がみられたことから， これが滲出液貯留の主たる要因としている。今 回の鼻すすり検査では，陽性率は約 2 割と少な かったが，陽性例の耳管通気圧は低值を示した ことから，耳管の通気圧の低い口蓋裂例では鼻 すすりで中耳が陰圧化する可能性が示された。

（2）耳管の動的換気能について

滲出性中耳炎を持つ口蓋裂例の耳管では，陽 圧テスト良好例は約半数であったが，陰圧テス 卜不良例が93. $5 \%$ と大半を占め，耳管の陰圧解 除能が障害されていることがわかった.

耳管の開大障害の原因としては，耳管の開大 筋である口蓋帆張筋の低形成 ${ }^{34)} や ，$ 走行異常に 
よる運動ベクトルの変位 ${ }^{20)}$ などが挙げられて きたが，耳管の枠組みが軟弱なため，筋の有効 な収縮が妨げられている可能性もある。

Bluestone ${ }^{373}$ 38) はこのような耳管の病態を floppy tube と呼び，器質的狭窄よりむむしろ 機能的狭窄が滲出性中耳炎の病因であり, 口蓋 裂例にはこのような耳管が多いてとを報告して いるが，今回の調査でもとのような耳管の病態 が確認された.

(3) 耳管の排泄能について

中耳の組織学的検討 ${ }^{39}$ 40) や滲出液の 細菌学 的検討 ${ }^{41)}$ 加 , 滲出性中耳炎の発症に炎症の関 与が示唆されているが，口蓋裂例の耳管の排泄 機能は過半数が正常で耳管の線毛機能はほぼ正 常に保たれていることから，その病因的意義は 少ないものと考えられた。

\section{6 小 括}

滲出性中耳炎に罹患した口蓋裂例の耳管で は，狭窄例は全くなく，むしろ開放傾向にあ り，耳管の閉鎖力が弱いととが主な病態である ことが示された，乙れに加え通常の滲出性中耳 炎と共通の障害因子として, 中耳の陰圧を嚥下 で解消できず，一旦中耳が陰圧となると耳管は 施錠（ロック）され嚥下では開かない脆弱な耳 管の病態が示された.

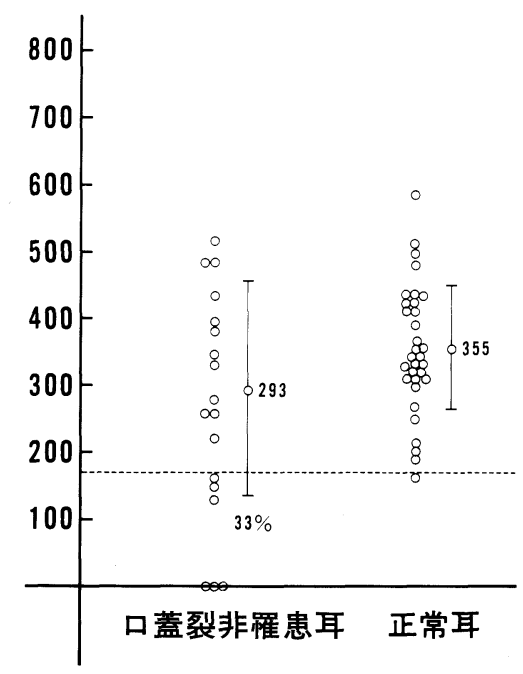

図13滲出性中耳炎非罹患耳の通気圧

\section{V 口蓋裂例片側淩出性中耳炎例の 非罹患耳の耳管機能}

1 目的

前述のような滲出性中耳炎を持つ口蓋裂例の 耳管の特徵が，口蓋裂に共通する所見であるの か否かを確認するため，片側性滲出性中耳炎を 持つ口蓋裂例の非罹患耳の耳管機能を調べた.

2 対 象

片側性の中耳疾患を持つ口蓋裂18例の非䍜患 耳を患者の同意の上で鼓膜穿刺し，前記の耳管 機能検査を行なった. 年齢は 4 歳から 38 歳（平 均14歳）であった。

\section{3 結 果}

耳管の通気圧の平均値は $293 \pm 160$ ミリ水柱で あり (図13), 正常下限以下の通気圧を示した例 が33\%（6耳）に認められた。 また陽圧保持が 不良な耳管が39\%（7 耳）に認められた。鼻す すり検査が陽性である耳管は 4 例に認められ， うち 1 例は耳管開放症，1 例は中耳陰圧を嚥下 で解消できたが，残り 2 例は耳管の施錠現象 （ロック）が生じて，唒下でもてれを解除でき なかった。

耳管の動的換気能は，陽圧テスト良好例が72 $\%$ (13耳)，不良が17\%（3 耳)，耳管開放のた め中耳に陽圧が負荷できない例が11\%（2 耳） に認められた（図14）。陰圧テストは良好例が $39 \%$ ( 7 耳), 不良例が61\%（11耳）であった。 排泄能は全例正常であった。

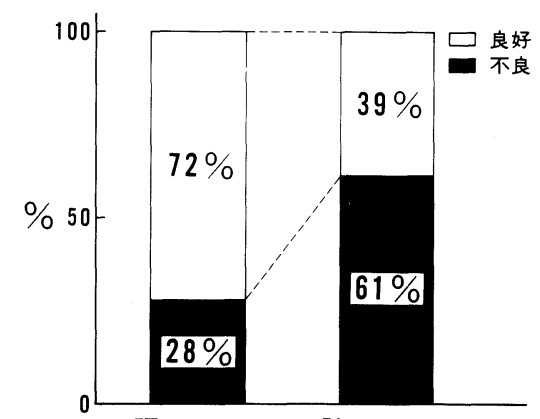

陽圧テスト 陰圧テスト

図14 滲出性中耳炎非罹患耳の動的換気能 


\section{4 考 按}

口蓋裂例では中耳疾患に罹患していない状態 でも耳管の通気圧が低く，閉鎖障害例が約 3 割 にみられたこと，および嚥下時の換気不良例が 過半数を占めたことは，口蓋裂例には耳管の閉 鎖障害と動的な耳管の換気能不良との二つの障 害因子が存在し，乙れが口蓋裂例における中耳 疾患多発の原因の一つ之考えられた。

VI 口蓋裂泳出性中耳炎難治例の耳管機能

1 目 的

口蓋裂例の滲出性中耳炎の中には，一度の鼓 室チューブ留置で治癒するものと，治療に抵抗 する難治例とがある．乙の様な臨床経過の違い に耳管がどのように関係しているかを，それぞ れの群での耳管機能の比較で明らかにしようと した.

\section{2 対 象}

2 回以上鼓室チューブの留置を要し，最終観 察日にチューブ留置の状態か滲出性中耳炎がな お存在する例を難治群とし， 1 回の鼓室チュー ブ留置で滲出性中耳炎が治瘾し，チューブ脱落 後 1 ケ月以上で滲出性中耳炎の徵候が全く認め られないものを治癒群とした。乙れら症例の治 癒確認のため鼓膜に小切開を加え，以下の耳管 機能㭘査を行った。治癒群は16耳で年齢 6 〜 31 歳 (平均 9 歳)，難治群は33耳で年齢 4 〜3歳 （平均 8 歳）であり，両群の 年齢に 有意差はな かった。

\section{3 結 果}

（1）難治群の耳管機能

耳管通気圧は平均 $211 \pm 139$ ミリ水柱で, 滲出 性中耳炎を持つ口蓋裂全体の $274 \pm 132$ ミリ水柱 と比較して有意に低值であった (Welch-t-test) （図15)。また非口蓋裂例の 正常下限（165ミリ 水柱）以下の通気圧を示す例が36\%（12耳）に みられ，乙の群での耳管通気圧の低值が明らか にされた。開放耳管は15\%（5 例）にみられ， これらは全て中耳陰圧で耳管が施錠され，かつ 嚥下で陰圧解除が不能であった。通気圧の低值 にとあない，耳管が保持できる陽圧值も低くな
り，200ミリ水柱の陽圧保持不能例が $73 \%$

耳）と大半を占めた（図16）。

耳管の動的換気能では，陰圧平衡能は全例で 不良であり，陽圧平衡能む良好例は $33 \%$ (11耳) にとどまった（図17)。排泄能は88\%（23耳）が

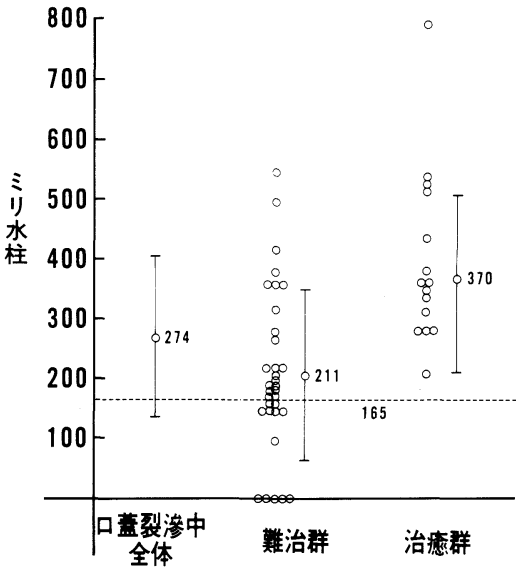

図15＼cjkstart滲出性中耳炎難治群の通気圧

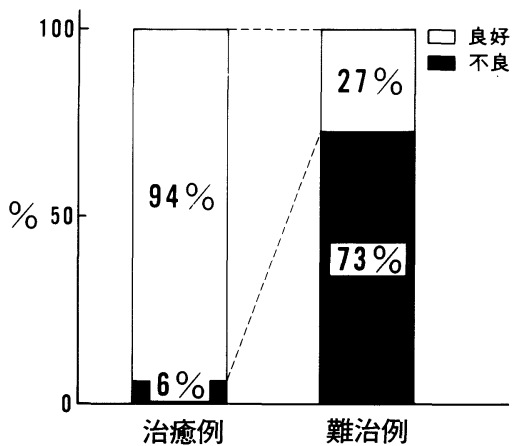

図16 滲出性中耳炎難治群の陽圧保持能

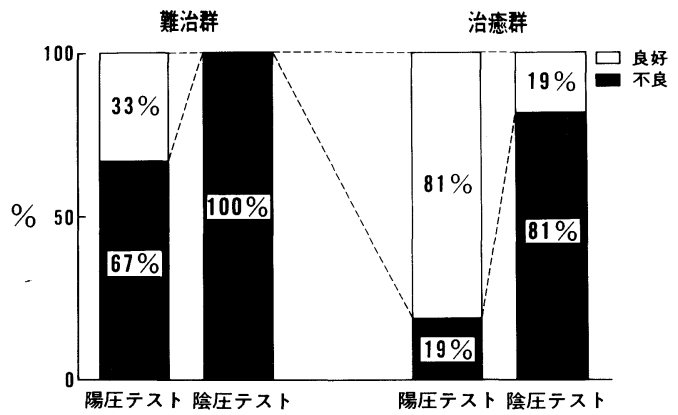

図17滲出性中耳炎難治群の動的換気能 
正常であった.

(2) 治癒群の耳管機能

耳管の通気圧は $370 \pm 158$ ミリ水柱で, 非口蓋 裂例の正常耳との間に有意差を認めず，また正 常下限より低值を示す例は 1 例のみであった （図15）。200ミリ水柱の陽圧は94\%（15耳）が 保持可能であった，鼻すすり検査で中耳の陰圧 を呈した例は全くみられなかった。

陽圧テストは81\% (13耳) が良好であったが, 陰圧テストは81\%（13耳）が不良であった。排 泄能は88\%（14耳）が正常であった。

\section{4 考 按}

(1) 静的耳管機能の比較

難治例の滲出性中耳炎群では, 耳管の通気圧 が異常に低いものが約三割にみとめられ，また 陽圧保持不能例が 7 割あり, 耳管の閉鎖力の乏 しさが示された. 藤田ら ${ }^{42)}$ は通常の滲出性中耳 炎難治群の $47 \%$ に耳管の通気圧の異常高值を, $12 \%$ 亿異常低值を認め, 乙れらの滲出性中耳炎 の難治の原因として耳管の器質的狭窄を推定し たが，口蓋裂例ではむしろ耳管の閉銧障害が難 治の原因であろうと考えられた。

一方滲出性中耳炎治癒群では耳管の通気圧は 正常範囲にあり，陽圧保持能むほぼ全例が良好 であることから，口蓋裂例においては耳管の閉 鎖能が滲出性中耳炎の治癒と関係する要因の一 つと考えられた.

\section{（2）動的耳管機能の比較}

陽圧平衡能良好は難治群の約 3 割にしかみら れないのに対して, 治癒群では約 7 割にみられ, 口蓋裂例の滲出性中耳炎において屯耳管の動的 換気能の改善がその予後に影響を及ぼすととが 示された。しかし陰圧平衡能は両群とも大半で 障害されており，中耳の陰圧を解消できないと いう基本的な病態に差はなかった. 高橋 ${ }^{43)}$ は非 口蓋裂例の治癒期の滲出性中耳炎の検討で, 陰 圧テストは90\%不良であったとしており， 口蓋 裂例に㧊いても耳管の動的換気能の障害が滲出 性中耳炎の素因的な障害因子であると考えら れた。

\section{(3) 排泄能の比較}

難治群，治癒群いずれにおいてもその約 9 割 が耳管の排泄能は正常であり, 線毛機能障害は 口蓋裂例の滲出性中耳炎では病因としての意義 が少ないことが再確認された。

以上より，口蓋裂例の滲出性中耳炎では，動 的な換気障害とともに耳管の閉鎖障害がその 病態と予後とに梁く係わっているととが示さ れた。

\section{5 小括}

滲出性中耳炎を持つ口蓋裂例で中耳疾患の病 期や罹患耳，予後などの因子で検討した所，耳 管の閉鎖障害が滲出性中耳炎の発症や予後と密 接に関係していることがわかった。また動的な 耳管換気能障害は口蓋裂例が共通して持つ危険 因子であるととがわかった。しかし耳管の線 毛機能障害は病因としての意義が少ないと考え られた。

\section{VII 総 括}

口蓋裂の中耳疾患と耳管の病態を口蓋裂 526 耳で検討した所，口蓋裂例の約半数で中耳疾患 がみられ，その大半は滲出性中耳炎であること が再確認された，このような口蓋裂の中耳疾患 多発の原因に鼻咽腔閉鎖不全が挙げられている が，今回，鼻咽腔閉鎖不全という共通の因子を 持っているが，一方に口蓋裂のない先天性鼻咽 腔閉鎖不全例と，他方未手術の粘膜下口蓋裂例 とで滲出性中耳炎の罹患率を調べた結果，筋層 に裂のない鼻咽腔閉鎖不全群の方が有意に耳疾 患が少ないことがわかり，鼻咽腔閉鎖不全因子 が直ちに滲出性中耳炎の原因とはなりえない事 が明らかにされた。 また，中耳疾患が口蓋裂の 裂型や裂側と関係しないととも再確認され，口 蓋裂という先天性疾患が両側の耳管に同程度の 器質的，機能的な障害をむたらしているてとが 推測された。

次に耳管とそれをとりまく筋肉などの解剖学 的異常と中耳疾患との関係を耳管咽頭口の内視 鏡的観察で調べた所，口蓋裂例では耳管咽頭口 が開大しない例が過半数を占め，乙れらには有 
意に滲出性中耳炎が多いことがわかった，今一 つの所見は耳管のフレームが軟弱で燕下や発声 時の口蓋帆挙筋の収縮で容易に耳管咽頭口が閉 塞することであり，乙れら耳管咽頭口の開大障 害が滲出性中耳炎発症の一要因であると考えら れた。

口蓋裂を持つ滲出性中耳炎の耳管機能の特徵 では，非口蓋裂の場合と同じく耳管の動的換気 能の障害が認められ，乙れは内視鏡検査で得ら れた耳管の開大障害が機能面で裏付けられたも のといえる. しかしこの耳管の換気能障害は口 蓋裂特有のあのではなく, 滲出性中耳炎発症の ための共通の障害因子と考えられた.

本研究で明らかにされた通常の滲出性中耳炎 例と口蓋裂例の耳管機能との主たる相違点は, 耳管の閉鎖力が弱いととであり，乙れは耳管の 通気圧検查, 圧負荷音響耳管検査, 耳管の陽圧 保持㭘査で明らかにされた。また耳疾患のない 口蓋裂例でも上述の耳管の閉鎖障害と動的換気 能の不良とが高率にみられたととから，てれら が口蓋裂例の中耳疾患の基盤にあることが示唆 された. 更に口蓋裂例の滲出性中耳炎の難治例 でも同様の特徵的な耳管障害がみられたととか ら，乙れらの耳管機能不全が滲出性中耳炎の予 後とあ関係するととがわかった。

以上を総合すると，口蓋裂例の滲出性中耳炎 の耳管は閉鎖障害をもち，乙れに加え口蓋裂の ない滲出性中耳炎と屯共通する因子として, 耳 管の動的換気能の障害があることがわかった. これらの口蓋裂例の耳管の障害因子が中耳疾患 多発の要因と考えられた。

\section{VIII まとめ}

口蓋裂例 526 耳の検討から，以下のととがわ かった。

1. 口蓋裂患者の $33 \%$ に滲出性中耳炎がみら れたが，裂型や裂側，鼻咽腔閉鎖不全と中耳疾 患には相関がなかった。

2. 口蓋裂例では耳管の開大障害があり，耳 管咽頭口の開大の有無と中耳疾患との間に有意 な相関がみられた。
3. 口蓋裂例の滲出性中耳炎では耳管の通気 圧が低く，閉鎖力が弱いことがわかった。この 閉鎖障害は滲出性中耳炎非罹患耳でも約 3 割 に, 滲出性中耳炎難治例では約 7 割にみとめら れ，口蓋裂耳管の特徵であることがわかった。

4. 滲出性中耳炎罹患耳の耳管の動的換気能 は過半数で障害されていたが，非罹患耳であ換 気能障害が認められ，口蓋裂例に共通する中耳 疾患の罹患因子であることがわかった。

5. 耳管の線毛排泄機能は口蓋裂例の中耳炎 において，病因的意義は少ないと考えられた。 以上のことより，耳管の閉鎖障害と動的換気能 障害とが，口蓋裂例の中耳疾患の多発と遷延化 の要因であると考えられた。

稿を終えるにあたり, 御指導, 御助言, ならびに御 校閲を賜った本庄 麗教授に深謝いたします.

なお本論文の一部は第48回耳鼻咽喉科臨床学会総会 (昭和61年 7 月 6 日, 於和歌山市), 第10回日本口蓋裂 学会総会 (昭和61年 7 月17日, 於長崎市), 第 4 回頭蓋 顎顔面外科学会総会 (昭和61年 9 月 27 日, 於大津市) そおいてロ演した。

\section{参考文献}

1) Alt A: Heilung der Taubstummheit erzielte durch Beseitigung einer Otorrhoe und einer angeborenen Gaumenspalte. Arch Augenheilk $7: 211 \sim 213,1878$.

2) Sataloff $J$ and Fraser $M:$ Hearing loss in children with cleft palates. Arch Otolaryngol 55 : 61 64, 1952.

3) Fara $\mathrm{M}$ and Dvorak $\mathrm{J}$ : Abnormal anatomy of the muscles of palatopharyngeal closure in cleft palates. Plastic and Reconstr Surg 46 : 488 497, 1970.

4) Ross MA : Functional anatomy of the tensor palati; its relevance in cleft palate surgery. Arch Otolaryngol $93: 1 \sim 8,1971$.

5 ) Odoi H, Proud GO and Toledo PS : Effects of pterygoid hamulotomy upon eustachian tube function. Laryngoscope $81: 1242 \sim 1244,1971$.

6) Doyle WJ, Cantekin EI, Bluestone CD, et al : Nonhuman primate model of cleft palate and 
its implications for middle ear pathology. Ann Otol Rhinol Laryngol 89 Suppl 68 : 41 46, 1980.

7 ) Dickson WM, Dickson DR and Rood SR : Anatomy of the eustachian tube and related structures in age-matched human fetuses with and without cleft palate. $\operatorname{Tr}$ Am Acad Ophthal \& Otol $79: 159 \sim 163,1975$.

8) Paradise JL, Bluestone $\mathrm{CD}$ and Felder $\mathrm{H}$ : The universality of otitis media in 50 infants with cleft palate. Pediatrics $44: 35 \sim 42,1969$.

9) Harker L and Severeid L : Cholesteatoma in the cleft palate. Cholesteatoma and Mastoid Surgery (ed by Sade J). pp 37 40, Kugler Publications, Amsterdam, 1982.

10) Webster JC : Middle ear function in the cleft palate patients. J Laryngol Otol $94: 31 \sim 37$, 1980.

11) Chaudhuri PK and Bowen-Jones E: An otorhinological study of children with cleft palates. J Laryngol Otol $92: 29 \sim 40,1978$.

12) Pannbacker $M:$ Hearing loss and cleft palate. Cleft Palate J $6: 50 \sim 56,1969$.

13) Yules RB : Hearing in cleft palate patients. Arch Otolaryngol $91:$ 319 323, 1970.

14）岡崎伸博, 本庄 縓, 松井博史, 他：口蓋裂小児 の中耳疾患について. 耳喉 $52: 471 \sim 474,1980$.

15) Skolnik EM : Otologic evaluation in cleft palate patients. Laryngoscope 68 : 1908 1949, 1958.

16) Spriesterbach DC, Lierle DM, Moll KL, et al: Hearing loss in children with cleft palates. Plast Reconstr Surg 30 : 336 347, 1962.

17) Graham MD : A longitudinal study of ear disease and hearing loss in patients with cleft lips and palates. Ann Otol Rhinol Laryngol $73: 34 \sim$ 47, 1964.

18) Bennet M, Ward $\mathrm{RH}$ and Tait $\mathrm{CH}$ : Otologicaudiologic study of cleft palate children. Laryngoscope $78:$ 1011 1019, 1968.

19）牛呂公一, 本庄 箃, 土師知行, 他: 口蓋裂小児 の中耳疾患. 日耳鼻 $85: 805 \sim 810,1982$.

20) Dickson DR : Anatomy of the normal and cleft palate eustachian tube. Ann Otol Rhinol Laryngol 85 Suppl $25: 25 \sim 29,1976$.

21) Latham RA, Long RE and Latham EA : Cleft palate velopharyngeal musculature in a fivemonth-old infant; a three dimensional histological reconstruction. Cleft Palate J $17: 1 \sim 16,1980$.

22) Doyle WJ, Kitajiri M and Sando I : The anatomy of the auditory tube and paratubal musculature in a one month old cleft palate infants. Cleft Palate J $20: 218 \sim 226,1983$.

23) Swarts JD, Rood SR and Doyle WJ : Fetal development of the auditory tube and paranasal musculature. Cleft Palate J 23 : 289 295, 1986.

24) Bluestone CD : Eustachian tube obstruction in the infant with cleft palate. Ann Otol Rhinol Laryngol Suppl $2: 1 \sim 30,1971$.

25）三苫藤吉郎, 本庄 㦑, 牛呂公一, 他 : 口蓋裂例 の耳管咽頭口所見一矛盾例について一. 耳鼻臨床 $78: 345 \sim 351,1985$.

26) Kriens $\mathrm{O}:$ Anatomy of the velopharyngeal area in cleft palate. Clin Plast Surg $2: 261 \sim 282$, 1975.

27) Holborow CA : Deafness associated with cleft palate. J Laryngol Otol $76: 762 \sim 773,1962$.

28）内藤 泰, 田坂康之, 本庄 嚴, 他: 口蓋裂の MRI (核磁気共鳴画像). 耳鼻臨床 $80: 435 \sim 440$, 1987.

29）本庄 篇 : 耳管と中耳病態. 進行印刷出版, 京都, 1987.

30）広野喜信，八木伸也，本庄 嚴：耳管閉鎖不全例 の圧負荷音響法による検討. 耳喉 59 : 23～28, 1987.

31) Falk B : Negative middle ear pressure induced by sniffing; a tympanometric study in persons with healthy ears. J of Otolaryngol $10: 299 \sim$ 305, 1981.

32) Rood SR: The nasopharyngeal orifice of the auditory tube; implications for tubal dynamics anatomy. Cleft Palate J $19: 119 \sim 128,1982$.

33) Surina I and Jagr J:Action potentials of levator and tensor muscles in patients with cleft palate. Acta Chirung Plastic $11: 21 \sim 30,1969$.

34) Doyle WJ : Eustachian tube function in special populations; cleft palate children. Ann Otol Rhinol Laryngol 94 Suppl $120:$ 39 40, 1985.

35) Doyle WJ, Reilly JS, Jardini L, et al : Effect of palatoplasty on the function of the eustachian 
tube in children with cleft palate. Cleft Palate J $23:$ 63 68, 1986.

36) Falk B and Magnuson B : Eustachian tube closing failure; ocurrence in patients with cleft palate and middle ear disease. Arch Otolaryngol $110: 10 \sim 14,1984$.

37) Bluestone CD, Beery QC, Cantekin EI, et al : Eustachian tube ventilatory function in relation to cleft palate. Ann Otol Rhinol Laryngol 84: 333 338, 1975.

38) Bluestone CD, Paradise JL, Beery QC, et al : Certain effects of cleft palate repair on eustachian tube function. Cleft Palate J $9: 183 \sim 193,1972$.

39) Stool SE and Randall P : Unexpected ear disease in infants with cleft palate. Cleft Palate J $4: 99 \sim 106,1967$.
40) Kitajiri M, Sando I, Hashida $Y$, et al : Histopathology of otitis media in infants with cleft and high-arched palates. Ann Otol Rhinol Laryngol $94: 44 \sim 50,1985$.

41）細見泰敏, 山本悦生,一色信彦, 他：口蓋裂患者 の中耳疾患一ことに中耳滲出液について一. 耳鼻 臨床 $76: 1377 \sim 1381,1983$.

42) 藤田明彦, 佐藤宏昭, 本庄 嚴, 他 : 滲出性中耳 炎難治例の検討. 耳鼻臨床 $81: 363 \sim 371,1988$.

43）高橋晴雄: 滲出性中耳炎之耳管. 耳鼻臨床 補22 : $1 \sim 20,1988$.

$\left(\begin{array}{l}\text { 原稿採択 : 平成元年 } 4 \text { 月 } 6 \text { 日 } \\ \text { 別刷請求先 : 田坂康之 } \\ \text { 个910 福井市月見2-4-1 } \\ \text { 福井赤十字病院耳鼻咽喉科 }\end{array}\right)$ 